\title{
PENGARUH PERSEPSI KUALITAS DAN KEPUASAN \\ TERHADAP LOYALITAS NASABAH (STUDI KASUS : NASABAH KOPERASI KREDIT (CREDIT UNION) MANDIRI TEBING TINGGI
}

\author{
Peran Simanihuruk, SE, M.Si
}

\begin{abstract}
Abstrak
Tujuan penelitian ini menganalisis pengaruh persepsi kualitas dan kepuasan terhadap loyalitas nasabah Koperasi Kredit (Credit Union) Mandiri ( Kopdit CU Mandiri). Manfaat penelitian, memberikan bukti empiris mengenai pengaruh variabel yang dapat mempengaruhi persepsi kualitas dan loyalitas nasabah. Jumlah sampel 96 nasabah, metode pengumpulan data dengan koesioner dan dokumentasi, metode analisis data digunakan regresi linier dan berganda dan untuk menguji hipotesis digunakan uji t dan uji F. Hasil penelitian menunjukkan bahwa variabel harga berpengaruh signifikan terhadap persepsi kualitas, variabel reputasi perusahaan berpengaruh signifikan terhadap persepsi kualitas, variabel persepsi kualitas berpengaruh signifikan terhadap variabel loyalitas nasabah, variabel kepuasan nasabah berpengaruh signifikan terhadap variabel loyalitas nasabah, variabel harga dan reputasi perusahaan mempunyai pengaruh yang positif terhadap persepsi kualitas dan variabel persepsi kualitas dan kepuasan nasabah mempunyai pengaruh yang positif terhadap loyalitas nasabah. Berdasarkan hasil penelitian, sebaiknya pihak Kopdit CU Mandiri memperhatikan variabel harga yang terkait dengan konsumen sasaran maupun pesaing, variabel reputasi perusahaan yang terkait dengan pengalaman, kompetensi dan keunggulan Kopdit CU Mandiri, variabel persepsi kualitas yang terkait dengan keandalan (Reliability), ketanggapan (Responsiveness), keyakinan (Assurance), empati (Empathy) dan Tangibles. variabel kepuasan nasabah supaya tetap dipertahankan yang terkait dengan kesesuaian harapan , persepsi kinerja dan penilaian nasabah dan mempertahankan variabel loyalitas nasabah yang terkait dengan Repeat Purchase, Retention dan Referalls.
\end{abstract}

Kata kunci : Harga, Reputasi Perusahaan, Persepsi Kualitas, Kepuasan Nasabah Loyalitas nasabah

\section{PENDAHULUAN}

Persaingan dunia bisnis jasa pada tahun terakhir ini semakin ketat dengan adanya kemajuan teknologi komunikasi dan informasi. Semakin mudahnya mendapat informasi maka alternatif pilihan produk/jasa yang tersedia di pasar semakin mudah didapatkan. Para produsen atau penjual berusaha memenuhi kebutuhan dan keinginan serta memberikan kepuasan secara maksimal kepada konsumen. Kinerja pelayanan yang tinggi merupakan hal yang sangat mendasar bagi kelangsungan hidup suatu perusahaan jasa. Pelayanan yang berkinerja tinggi adalah pelayanan yang 
mampu memberikan kepuasan terhadap kebutuhan nasabah atau mampu melebihi harapan nasabah (Anderson, Fornell, dan Lehmann dalam Diana Puspitasari 2006).

Persepsi kualitas (perceived quality) merupakan persepsi nasabah terhadap keseluruhan kualitas atau keunggulan suatu produk atau jasa layanan berkaitan dengan apa yang diharapkan oleh Nasabah. Aaker (1997) menyatakan bahwa persepsi kualitas merupakan persepsi para Nasabah, oleh sebab itu persepsi kualitas tidak dapat ditetapkan secara obyektif. Selain itu, persepsi nasabah akan melibatkan apa yang penting bagi nasabah karena setiap nasabah memiliki kepentingan yang berbedabeda terhadap suatu produk atau jasa .

Pemenuhan harapan nasabah yang sesuai dengan yang dipersepsikan akan menciptakan kepuasan nasabah. Kepuasan nasabah merupakan suatu tingkat perasaan nasabah yang diperoleh setelah menikmati bisnis jasa yang ditawarkan. Kepuasan nasabah didefinisikan sebagai sikap berkenaan dengan barang atau jasa setelah diterima dan dipakai. Cronin dan Taylor dalam Diana Puspitasari 2006 dalam penelitiannya berhasil membuktikan bahwa kepuasan nasabah ditentukan oleh penilaian nasabah terhadap kualitas pelayanan yang diberikan. Kepuasan nasabah akan dipengaruhi oleh harapan, persepsi kinerja, dan penilaian atas kinerja produk atau jasa yang dikonsumsi. Terdapat korelasi positif yang kuat antara persepsi kinerja terhadap kepuasan nasabah . Oliver dalam Diana Puspitasari 2006, menyatakan bahwa kepuasan nasabah merupakan tingkat perasaan seseorang setelah membandingkan kinerja atau hasil yang dirasakannya dengan harapan.

Kepuasan nasabah akan menciptakan loyalitas nasabah tersebut untuk tetap menggunakan bisnis jasa yang ditawarkan. Loyalitas dapat diartikan sebagai suatu kesetiaan. Kesetiaan timbul tanpa adanya paksaan, tetapi timbul dari kesadaran sendiri pada masa lalu. Usaha yang dilakukan untuk menciptakan kepuasaan konsumen lebih cenderung mempengaruhi sikap konsumen. Sedangkan konsep loyalitas konsumen lebih menekankan kepada perilaku pembeliannya. Loyalitas nasabah merupakan salah satu tujuan inti yang diupayakan dalam pemasaran modern. Karena dengan adanya loyalitas Nasabah perusahaan akan mendapatkan keuntungan dalam jangka panjang.

Tujuan umum dari hubungan pemasaran adalah untuk membangun dan mempertahankan nasabah yang dapat menguntungkan perusahaan (Zeithaml dan Bitner, 1996). Nasabah merupakan aset yang memegang peranan penting untuk menentukan keberhasilan perusahaan. Mengingat 
nasabah mampu mencerminkan potensi pertumbuhan perusahaan dimasa mendatang maka upaya untuk menciptakan dan mempertahankan Nasabah menjadi prioritas utama bagi perusahaan.

Kepuasan nasabah merupakan hasil dari perbandingan antara harapan dan kenyataan yang diterima nasabah setelah mengkonsumsi barang atau jasa. Berkaitan dengan loyalitas nasabah, Anderson, Fornell, dan Lehmann (1994) menyatakan bahwa apabila nasabah puas terhadap barang atau kualitas layanan yang diberikan maka akan timbul loyalitas Nasabah sehingga minat beli nasabah meningkat dan membuat Nasabah kembali melakukan pembelian ulang (repurchase). Nasabah yang puas disebut sebagai retained customers sedangkan Nasabah yang tidak puas adalah lost customers. Nasabah yang bertahan (retained customers) memiliki peranan penting dalam persaingan bisnis yang ketat bagi pencapaian performa bisnis yang tinggi (Crane dalam Puspitasari, 2006). Sehingga strategi kualitas pelayanan yang mampu meningkatkan jumlah Nasabah yang bertahan (customers retained rate) menjadi fokus utama dalam era persaingan bisnis jasa yang ketat.

Kopdit CU Mandiri sebagai entitas bisnis jasa yang bergerak dalam industri jasa simpan pinjam sudah semestinya berorientasi kepada kualitas layanan dan kepuasan nasabah. Nasabah yang puas merupakan salah satu asset penting untuk kelangsungan hidup dan perkembangan bisnis itu sendiri. Pengelolaan strategi-strategi yang tepat untuk menarik nasabah perlu direncanakan secara matang agar nasabah mau membeli produk atau jasa yang dihasilkan.

Fenomena yang terjadi saat ini yaitu adanya perang harga sesama kopdit seperti biaya pendaftaran, simpanan wajib, tingkat bunga tabungan, tingkat bunga pinjaman dan sebagainya. Dalam rangka meningkatkan kualitas pelayanan Kopdit CU Mandiri telah memiliki 30 kantor cabang diberbagai daerah/kota. Dari penelitian yang telah dilakukan memberikan respon dari nasabah bahwa kepercayaan masyarakat terhadap pelayanan jasa yang semakin tinggi sehingga mereka merasa aman dalam menabung dan meminjam.

Hal tersebut selaras dengan penelitian yang telah dilakukan oleh Brown dan Dacin (1997) dimana reputasi perusahaan sangat penting dari sudut pandang nasabah untuk memberikan gambaran terhadap kualitas produk atau jasa yang dihasilkan, dimana harga yang tinggi dari suatu merek seringkali dipersepsikan memiliki kualitas yang tinggi (Chapman dan Wahlers, 1999). Seperti dikemukakan oleh para peneliti dalam Hellier, Geursen, Carr, dan Rickard (2003) dikatakan bahwa kepuasan Nasabah 
secara keseluruhan pada layanan jasa berasosiasi kuat terhadap perilaku konsumen untuk menggunakan kembali jasa dari penyedia yang sama. Zeithaml (1988) mengidentifikasikan persepsi kualitas sebagai komponen dari nilai merek dimana persepsi kualitas yang tinggi akan mengarahkan konsumen untuk memilih merek tersebut dibandingkan dengan merek pesaing. Persepsi kualitas yang dirasakan oleh konsumen berpengaruh terhadap loyalitas konsumen tersebut untuk membeli sebuah produk (Chapman dan Wahlers, 1999). Oleh karena itu, peneliti ingin meneliti dengan topik : Pengaruh Persepsi Kualitas dan Kepuasan Terhadap Loyalitas Nasabah Pada Kopdit CU Mandiri Cabang Medan .

\section{PERUMUSAN MASALAH}

Berdasarkan fenomena di atas, maka perumusan masalah dalam penelitian ini :

1. Apakah harga dan reputasi perusahaan berpengaruh positif terhadap persepsi kualitas ?

2. Apakah persepsi kualitas dan kepuasan nasabah berpengaruh positif terhadap loyalitas nasabah?

3. Apakah harga dan reputasi perusahaan mempunyai pengaruh yang signifikan secara simultan dan parsial terhadap persepsi kualitas ?

4. Apakah persepsi kualitas dan kepuasan nasabah mempunyai pengaruh yang signifikan secara simultan dan parsial terhadap loyalitas nasabah ?

\section{TINJAUAN PUSTAKA}

\section{Persepsi Kualitas}

Berdasarkan hasil penelitian, persepsi kualitas (perceived quality) menurut Aaker (1997) dapat didefinisikan sebagai persepsi nasabah terhadap keseluruhan kualitas atau keunggulan suatu produk/jasa layanan berkaitan dengan apa yang diharapkan oleh nasabah. Aaker (1997) menegaskan persepsi kualitas merupakan persepsi para nasabah, maka persepsi kualitas tidak dapat ditetapkan secara obyektif. Persepsi nasabah akan melibatkan apa yang penting bagi nasabah karena setiap nasabah memiliki kepentingan yang berbeda-beda terhadap suatu produk/jasa (Aaker 1997). Maka persepsi kualitas berarti akan membahas keterlibatan dan kepentingan nasabah. Persepsi kualitas yang tinggi menunjukkan bahwa melalui penggunaan dalam jangka waktu yang panjang, konsumen memperoleh diferensiasi dan superioritas dari merek tersebut. Zeithaml mengidentifikasikan persepsi kualitas sebagai komponen dari nilai merek dimana persepsi kualitas yang tinggi akan mengarahkan konsumen untuk 
memilih merek tersebut dibandingkan dengan merek pesaing. Persepsi kualitas yang dirasakan berpengaruh terhadap kesediaan konsumen untuk membeli sebuah produk. Semakin tinggi nilai yang dirasakan oleh konsumen, maka akan semakin tinggi pula kesediaan konsumen untuk melakukan pembelian (Chapman dan Wahlers, 1999).

Persepsi kualitas mencerminkan perasaan Nasabah yang tidak nampak dan secara menyeluruh mengenai suatu merek. Akan tetapi, biasanya persepsi kualitas didasarkan pada dimensi-dimensi yang termasuk dalam karakteristik produk tersebut dimana merek dikaitkan dengan halhal seperti keandalan dan kinerja. Lima dimensi kualitas jasa (Parasuraman, Zeithaml, dan Berry, 1988; Zeithaml et al, 1996) yang dipergunakan untuk memahami harapan dan persepsi konsumen terhadap kualitas jasa tersebut adalah :

1. Keandalan (Reliability). Kemampuan untuk melaksanakan jasa yang dijanjikan dengan tepat dan terpercaya.

2. Ketanggapan (Responsiveness). Kemauan perusahaan untuk membantu Nasabah dan memberikan jasa dengan cepat.

3. Keyakinan (Assurance). Pengetahuan dan keramahtamahan para karyawan serta kemampuan mereka untuk menimbulkan kepercayaan dan keyakinan.

4. Empati (Empathy). Syarat untuk peduli, memberi perhatian pribadi bagi Nasabah.

5. Berwujud (Tangibles). Penampilan fasilitas fisik (interior dan eksterior), peralatan, karyawan, dan media komunikasi.

Berdasarkan hasil penelitian diatas maka variabel persepsi kualitas dapat dibentuk dari tiga indikator, yaitu keandalan, ketanggapan, keyakinan, empati dan berujud. 
Gambar 1. Indikator-indikator Persepsi Kualitas

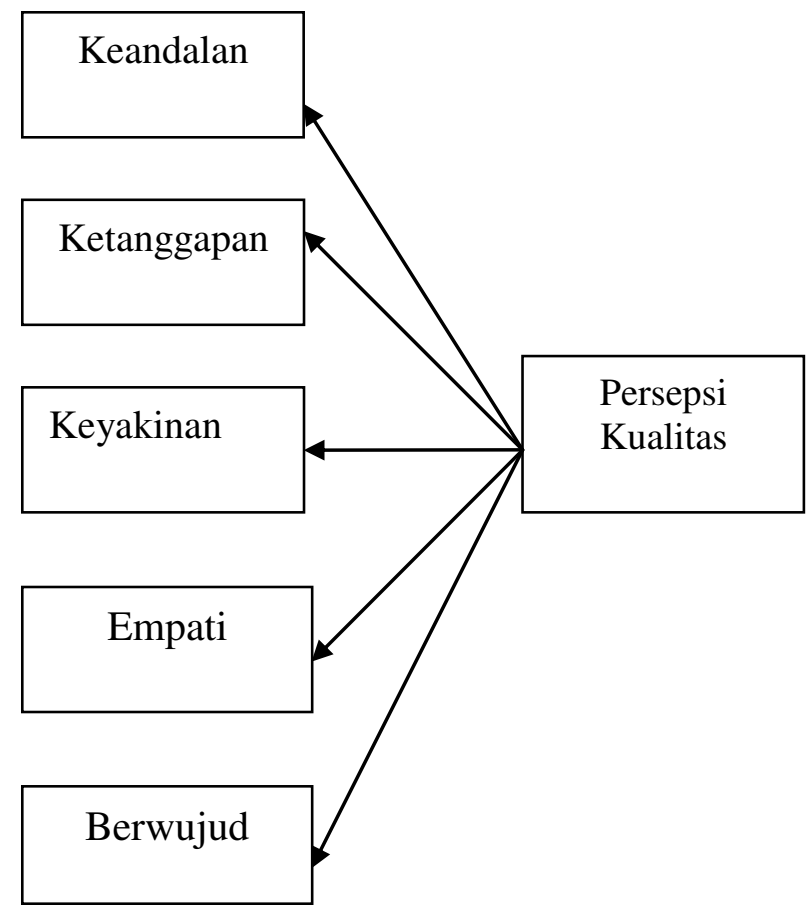

Sumber : Parasuraman et al. (1988) dan Zeithaml et al. (1996) dikembangkan dalam penelitian ini.

\section{Kepuasan Nasabah}

Kepuasan nasabah/nasabah didefinisikan sebagai semua sikap berkenaan dengan barang atau jasa setelah diterima dan dipakai. Kepuasan (satisfaction) adalah pilihan setelah evaluasi penilaian dari sebuah transakasi yang spesifik (Cronin \& Taylor, 1992). Cronin dan Taylor (1994) dalam penelitiannya berhasil membuktikan bahwa kepuasan nasabah ditentukan oleh penilaian nasabah terhadap kualitas pelayanan yang diberikan. Kepuasan nasabah menurut Spreng, Mackenzie \& Olshavsky (1996) akan dipengaruhi oleh harapan, persepsi kinerja, dan penilaian atas kinerja produk atau jasa yang dikonsumsi. Terdapat korelasi positif yang kuat antara persepsi kinerja terhadap kepuasan nasabah (Anderson, Fornell, dan Lehmann, 1994; Anderson dan Sullivan, 1993). Oliver (1993) menyatakan bahwa kepuasan merupakan tingkat perasaan seseorang setelah membandingkan kinerja atau hasil yang dirasakannya dengan harapan. Tse dan Wilton (1988) menyatakan bahwa kepuasan atau 
ketidakpuasan nasabah adalah merupakan respon nasabah terhadap evaluasi ketidaksesuaian yang dirasakan antara harapan sebelumnya dan kinerja aktual produk setelah pemakaiannya. Oliver (1993) meneliti mengenai kepuasan konsumen yang menunjukkan adanya pengaruh positif antara pengalaman pembelian sebelumnya terhadap tingkat kepuasan. Dengan adanya pengalaman terhadap pembelian sebelumnya kemungkinan hanya sedikit ketidaksesuaian antara harapan dan kinerja serta kemungkinan kecil terhadap ketidakpuasan. Berdasarkan pengalaman yang diperolehnya, nasabah memiliki kecenderungan untuk membangun nilainilai ekspektasi tertentu. Nilai ekspektasi tersebut akan memberikan dampak bagi nasabah untuk melakukan perbandingan terhadap kompetitor dari produk yang pernah dirasakannya. Secara langsung penilaian tersebut akan mempengaruhi pandangan dan penilaian nasabah terhadap perusahaan kompetitor. Berdasarkan hal-hal tersebut maka variabel kepuasan Nasabah dapat dibentuk dari tiga indikator, yaitu kesesuaian harapan, persepsi kinerja, dan penilaian nasabah.

Gambar 2. Indikator-indikator Kepuasan Nasabah

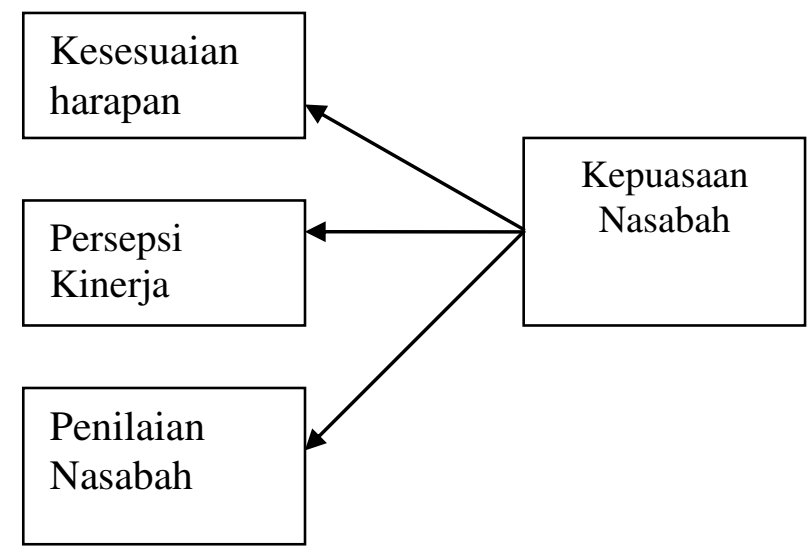

Sumber : Spreng, Mackenzie \& Olshavsky (1996) dikembangkan dalam penelitian ini

\section{Harga}

Harga merupakan besarnya pengorbanan yang dilakukan oleh konsumen untuk memperoleh sebuah produk atau jasa yang dibutuhkan (Zeithaml, 1988). Stedman (2000) mengidentifikasikan bahwa harga merupakan salah satu factor penting yang dapat mempengaruhi perilaku 
konsumen dalam pembelian merek, karena suatu barang atau jasa pastilah mempunyai nilai. Sedangkan nilai itu sendiri didasarkan dari harga, yang merupakan tolak ukur dari barang maupun jasa yang bersangkutan. Kennedy (1994) mengemukakan bahwa penjualan produk berkualitas tinggi kemungkinan dapat ditandai berdasarkan harga yang tinggi pula. Konsumen seringkali menggunakan harga sebagai petunjuk ekstrinsik atau indikator dari kualitas ataupun manfaat suatu produk. Hasil dari beberapa penelitian mengemukakan bahwa harga yang tinggi dari suatu merek seringkali dipersepsikan memiliki kualitas yang tinggi dan tidak peka terhadap persaingan potongan harga seperti merek-merek dengan harga yang rendah (Yoo, Donthu, dan Lee, 2000). Harga yang tinggi dapat menimbulkan persepsi kualitas produk atau jasa yang tinggi pula dari suatu merek (Monroe, 1973 dalam Ward, Chitty, and Achard, 2005; Dodds, Grewal, dan Monroe, 1991). Dalam penelitiannya, Ward, Chitty, and Achard (2005) mengukur persepsi harga dari konsumen dengan perkiraan besarnya harga yang bersedia dibayar oleh mereka untuk tiap merek terlibat. Teknik tersebut juga digunakan oleh Al-Sabbahy, Ekinci, dan Riley (2004) menilai persepsi responden terhadap kewajaran harga yang harus dibayar beradasarkan internal feeling dan pengetahuan mereka atas harga dari penyedia jasa lainnya pada bidang

yang sama.

Menurut Kotler (2001) dalam membuat keputusan mengenai harga harus memperhatikan atau harga sangat dipengaruhi oleh :

1. Konsumen sasaran. Apabila konsumen sasaran suatu perusahaan adalah konsumen tingkat atas maka perusahaan akan cenderung menetapkan harga yang tinggi.

2. Permintaan konsumen. Jika terjadi permintaan yang cukup tinggi terhadap suatu produk dan jumlah barang yang tersedia sedikit maka perusahaan cenderung menetapkan harga cukup tinggi.

3. Pesaing . Jika dalam suatu pasar terdapat banyak pesaing yang menjual produk yang sejenis, produsen akan menetapkan harga yang rendah atau bersaing.

Berdasarkan pada penelitian-penelitian tersebut diatas maka variabel harga dapat dibentuk dari tiga indikator, yaitu perkiraan harga, kesesuaian pengorbanan, dan kewajaran harga. 
Gambar 3. Indikator-indikator Harga

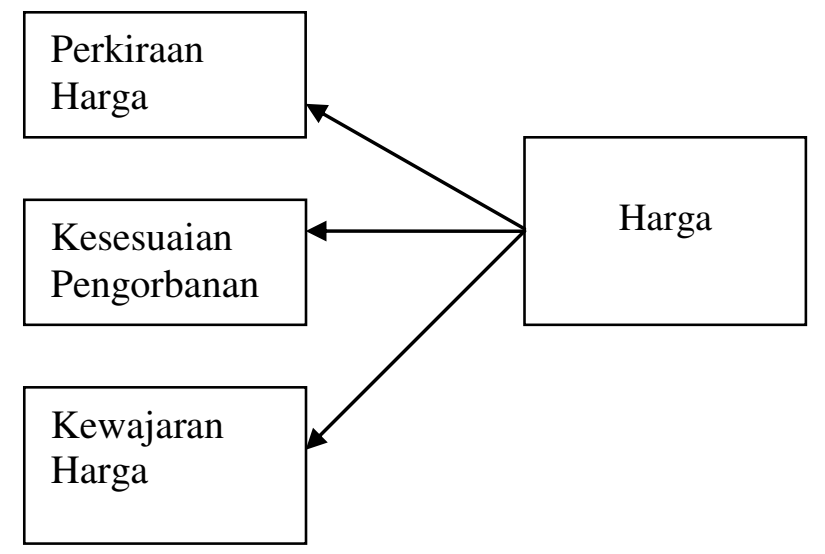

Sumber : Ward, Chitty, dan Achard (2005); Al-Sabbahy, Ekinci, dan Riley (2004); Zeithaml (1988) dikembangkan dalam penelitian ini

\section{Reputasi Perusahaan}

Zeithaml (1988) mengemukakan bahwa kualitas yang dirasakan dari suatu produk atau jasa erat hubungannya dengan reputasi yang diasosiasikan dengan nama merek. Herbig, Milewicz dan Golden (1994) menyatakan bahwa reputasi perusahaan dapat dilihat dari kompetensi perusahaan tersebut dan keunggulan dibandingkan dengan kompetitornya. Moorman dan Minner (1997) menyatakan bahwa keberhasilan perusahaan secara maksimal dapat dicapai apabila perusahaan tersebut fokus terhadap core business, sebab hal itu akan merefleksikan core competencies yang mereka punyai. Keahlian perusahaan tercermin dalam pengetahuan dan pengalaman perusahaan tersebut dalam industri yang dimasukinya (Brown dan Dacin, 1997; Moorman dan Miner, 1997). Menurut Brown dan Dacin (1997) reputasi perusahaan sangat penting dari sudut pandang Nasabah untuk memberikan gambaran terhadap kualitas produk atau jasa yang dihasilkan. Reputasi dari perusahaan dalam sudut pandang Nasabah dapat dijadikan jaminan bagi Nasabah untuk menilai kualitas produk atau jasa Berdasarkan pernyataan-pernyataan tersebut maka variabel reputasi perusahaan dibentuk oleh tiga indikator, yaitu pengalaman perusahaan dalam industri yang dimasukinya, kompetensi perusahaan, dan keunggulan perusahaan dibanding kompetitor. 
Gambar 4. Indikator-indikator Reputasi Perusahaan

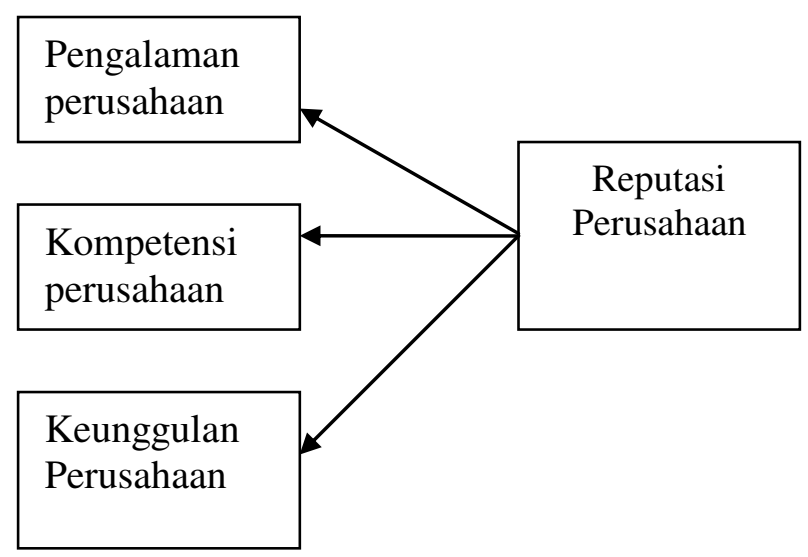

Sumber : Herbig, Milewicz dan Golden (1994); Brown dan Dacin (1997) dikembangkan dalam penelitian ini

\section{Loyalitas Nasabah}

Loyalitas nasabah merupakan salah satu tujuan inti yang diupayakan dalam pemasaran modern. Karena dengan adanya loyalitas nasabah perusahaan akan mendapatkan keuntungan dalam jangka panjang. Selanjutnya (Griffin, 2003:223) mengemukakan keuntungan-keuntungan yang akan diperoleh perusahaan apabila memiliki nasabah yang loyal antara lain:

a. Mengurangi biaya pemasaran (karena biaya untuk menarik nasabah baru lebih mahal)

b. Mengurangi biaya transaksi (seperti biaya negosiasi kontrak, pemrosesanpesanan, dll.)

c. Mengurangi biaya turnover nasabah (karena pergantian nasabah yang lebih sedikit)

d. Meningkatkan penjualan silang yang akan memperbesar pangsa pasar perusahaan.

e. Word of mouth yang lebih positif dengan asumsi bahwa nasabah yang loyal juga berarti yang merasa puas.

Ciri - ciri Nasabah yang Loyal:

a. Makes regular repeat purchase (melakukan pembelian ulang secara teratur)

b. Purchases across product and service lines (melakukan pembelian lini produk yang lain dari perusahaan yang bersangkutan) 
c. Refers others (memberikan referensi kepada orang lain)

d. Demonstratres in immunity to the pull of the competition (menunjukkan kekebalan terhadap tarikkan pesaing)

Indikator dari loyalitas nasabah (Kottler \& Keller, 2006:57) adalah Repeat Purchase (Kesetiaan terhadap pembelian produk); Retention (Ketahanan terhadap pengaruh yang negatip mengenai perusahaan); Referalls (Mereferensikan secara total eksistensi perusahaan).

Gambar 5. Indikator-indikator Loyalitas Nasabah

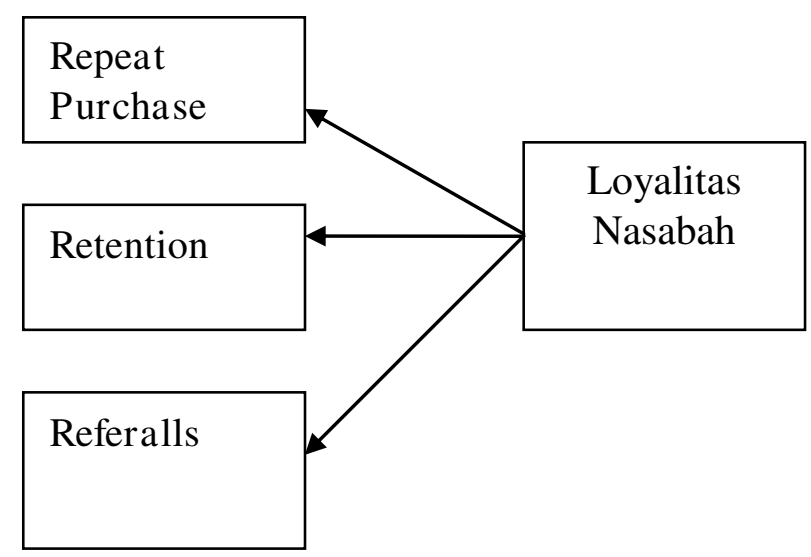

Sumber : Kottler \& Keller, 2006:57) dikembangkan dalam penelitian ini

\section{Kerangka Pemikiran Teoritis}

Berdasarkan telaah pustaka yang telah dikemukakan di atas, maka kerangka pemikiran dalam penelitian ini dapat dikembangkan sebagai berikut : 
Gambar 6. Kerangka Pemikiran Teoritis

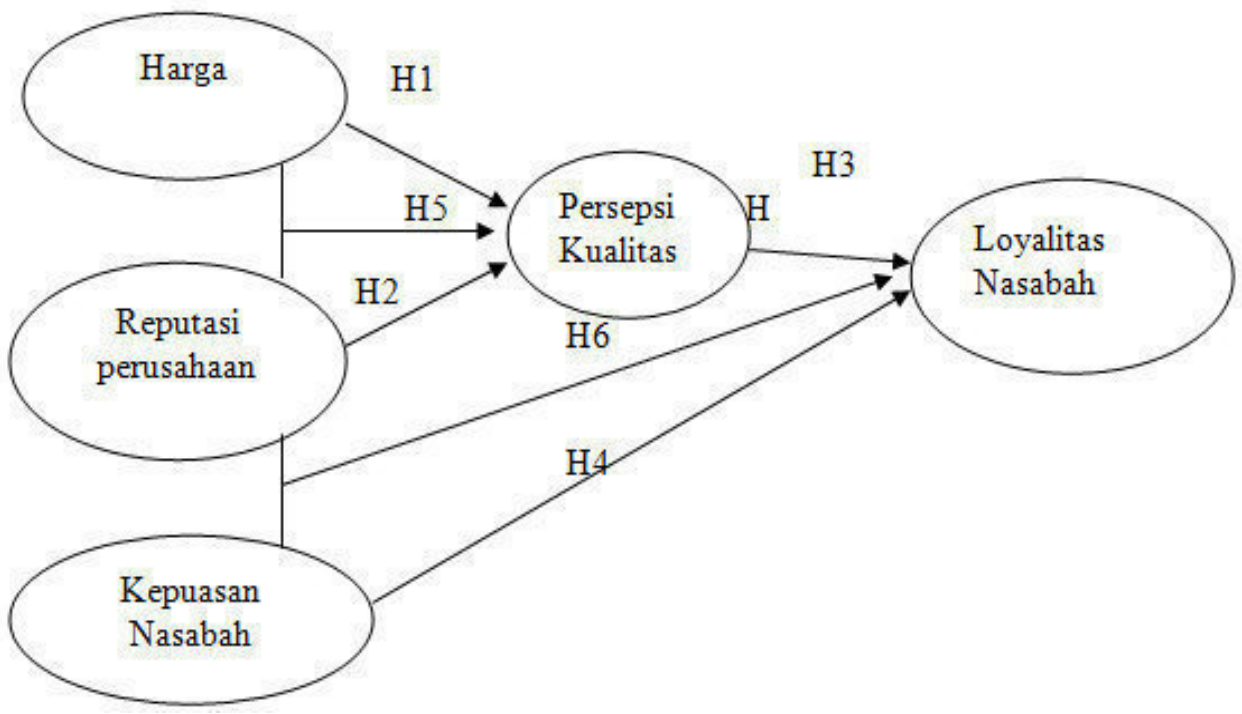

Sumber : Dikembangkan untuk penelitian ini

\section{Perumusan Hipotesis}

Berdasarkan kerangka pemikiran di atas , maka dirumuskan hipotesis :

1. Ada pengaruh harga terhadap persepsi kualitas.

2. Ada pengaruh reputasi perusahaan terhadap persepsi kualitas.

3. Ada pengaruh persepsi kualitas terhadap loyalitas nasabah.

4. Ada pengaruh kepuasan nasabah terhadap loyalitas nasabah.

5. Ada pengaruh harga dan reputasi perusahaan terhadap persepsi kualitas

6. Ada pengaruh persepsi kualitas dan kepuasan nasabah terhadap loyalitas nasabah.

\section{METODE PENELITIAN}

\section{Populasi dan Sampel}

Populasi pada penelitian ini adalah seluruh Nasabah Kopdit CU Mandiri Cabang Medan. Sampel penelitian ini sebagian dari anggota populasi. Pengambilan sampel secara purposive sampling. Berdasarkan tingkat keyakinan $95 \%\left(\alpha=5 \%, Z^{1} / 2 \alpha=1,96\right)$, kesalahan maksimum $(\varepsilon)=$ 
0,1 dan standar deviasi $(\sigma)=0,5$ maka rumus penentuan sampel (Supranto, 2001: 113):

$$
\begin{aligned}
\mathrm{n} & =\left(\frac{\mathrm{Z}_{\alpha / 2}{ }^{2} \times \sigma}{\varepsilon}\right)^{2} \\
& =\left(\frac{1,96 \times 0,5}{0,1}\right)^{2} \\
& =96,04 \text { orang }
\end{aligned}
$$

Maka jumlah sampel (n) $=96$ nasabah.

\section{Operasionalisasi Variabel}

Defenisi operasionalisasi variabel yang diteliti dapat dilihat pada tabel berikut:

Tabel 1. Definisi Operasional Variabel

\begin{tabular}{|l|l|l|l|}
\hline Variabel & Definisi Operasional & \multicolumn{1}{|c|}{ Indikator } & Pengukuran \\
\hline Harga & $\begin{array}{l}\text { Suatu pengorbanan } \\
\text { yang di persepsikan } \\
\text { oleh konsumen }\end{array}$ & $\begin{array}{l}\text { Perkiraan harga } \\
\text { Kesesuaian Pengorbanan } \\
\text { Kewajaran harga }\end{array}$ & Ordinal \\
\hline $\begin{array}{l}\text { Reputasi } \\
\text { Perusahaan }\end{array}$ & $\begin{array}{l}\text { Kepercayaan konsumen } \\
\text { atas nama baik dari } \\
\text { penyedia jasa }\end{array}$ & $\begin{array}{l}\text { Pengalaman perusahaan } \\
\text { Kompetensi perusahaan } \\
\text { Keunggulan perusahaan }\end{array}$ & Ordinal \\
\hline $\begin{array}{l}\text { Kepuasan } \\
\text { Nasabah }\end{array}$ & $\begin{array}{l}\text { Tingkat kepuasan } \\
\text { yang diperoleh dari } \\
\text { kemampuan penyedia } \\
\text { untuk memenuhi } \\
\text { harapan dan kebutuhan } \\
\text { nasabah }\end{array}$ & $\begin{array}{l}\text { Kesesuaian harapan } \\
\text { Persepsi kinerja } \\
\text { Penilaian Nasabah }\end{array}$ & Ordinal \\
\hline $\begin{array}{l}\text { Persepsi } \\
\text { Kualitas } \\
\text { keseluruhan kualitas } \\
\text { atau keunggulan suatu } \\
\text { produk yang } \\
\text { diharapkan oleh } \\
\text { nasabah }\end{array}$ & $\begin{array}{l}\text { Keandalan, Ketanggapan } \\
\text { Keyakinan, Empati } \\
\text { Berwujud }\end{array}$ & Ordinal \\
\hline $\begin{array}{l}\text { Leyalitas } \\
\text { Nasabah } \\
\text { menggunakan } \\
\text { produk/jasa yang } \\
\text { ditawarkan produsen }\end{array}$ & $\begin{array}{l}\text { Retention } \\
\text { Referalls }\end{array}$ & Ordinal \\
\hline
\end{tabular}

Sumber : Dikembangkan untuk penelitian ini 


\section{Teknik Pengumpulan Data}

Pada penelitian ini digunakan metode pengumpulan data primer melalui metode survei yang terdiri dari wawancara dan kuisioner sebagai berikut :

1. Wawancara. Wawancara merupakan teknik pengumpulan data dalam metode survei yang menggunakan pertanyaan secara lisan kepada subyek penelitian.

2. Kuisioner. Koesioner merupakan metode pengumpulan data yang diperoleh dari jawaban yang diberikan responden berdasarkan daftar pertanyaan yang telah disusun sebelumnya. Pada penelitian ini digunakan koesioner dengan skala ordinal dimana pernyataanpernyataan dalam koesioner dibuat dengan nilai 1 sampai dengan 5 untuk mewakili pendapat responden .

\section{Teknik Analisis}

Metode analisis yang digunakan adalah regresi linier sederhana dan berganda untuk mengetahui pengaruh variabel bebas terhadap variabel terikat (Sugiyono, 2004) dengan rumus:

$$
\begin{aligned}
& \mathrm{Y}=\beta_{0}+\beta_{1} \mathrm{X}+\varepsilon \ldots \ldots \ldots \ldots \\
& \mathrm{Y}=\beta_{0}+\beta_{1} \mathrm{X} 1+\beta_{2} \mathrm{X} 2+\varepsilon
\end{aligned}
$$

Keterangan :

$\mathrm{Y}=$ Variabel terikat, $\mathrm{X} 1$ dan $\mathrm{X} 2=$ Variabel bebas, $\beta_{0}=$ Konstanta, $\beta_{1}$ dan $\beta_{1}=$ Koefisien regresi, $\varepsilon=$ Tingkat kesalahan estimasi

Persamaan di atas diaplikasikan dalam penelitian ini dengan rumus :

$$
\begin{aligned}
& \mathrm{PK}=\beta_{0}+\beta_{1} \mathrm{H}+\varepsilon \ldots \ldots \ldots \ldots \ldots \\
& \mathrm{PK}=\beta_{0}+\beta_{1} \mathrm{RP}+\varepsilon \ldots \ldots \ldots \ldots \ldots \\
& \mathrm{LP}=\beta_{0}+\beta_{1} \mathrm{PK}+\varepsilon \ldots \ldots \ldots \ldots \ldots \\
& \mathrm{LP}=\beta_{0}+\beta_{1} \mathrm{KP}+\varepsilon \ldots \ldots \ldots \ldots \ldots \\
& \mathrm{PK}=\beta_{0}+\beta_{1} \mathrm{H}+\beta_{2} \mathrm{RP}+\varepsilon \ldots \\
& \mathrm{LP}=\beta_{0}+\beta_{1} \mathrm{KP}+\beta_{2} \mathrm{KP}+\varepsilon
\end{aligned}
$$

\section{Keterangan :}

PK = Persepsi Kualitas, $\mathrm{H}=$ Harga, $\mathrm{RP}=$ Reputasi Perusahaan, $\mathrm{PK}=$ Persepsi Kualitas, KP $=$ Kepuasan Nasabah, LP $=$ Loyalitas nasabah, $\beta_{0}=$ Konstanta, $\beta_{1}$ dan $\beta_{2}=$ Koefisien regresi, $\varepsilon=$ Tingkat kesalahan estimasi 
Untuk membuktikan apakah hipotesis digunakan uji $\mathrm{F}$ dan $\mathrm{t}$.

\section{A. Uji F}

1. $\mathrm{H}_{0}: \beta \mathrm{i}=0$, artinya variabel bebas tidak berpengaruh signifikan secara parsial dan simultan terhadap variabel terikat.

$\mathrm{H}_{1}: \beta \mathrm{i} \neq 0$, artinya variabel bebas berpengaruh signifikan secara parsial dan simultan terhadap variabel terikat.

2. Level of significan $(1-\alpha)=95 \%$, jumlah $n=258$ nasabah.

3. Uji statistik F:

$$
\mathrm{F}=\frac{\mathrm{R}^{2} /[\mathrm{k}-1]}{\left[1-\mathrm{R}^{2}\right] /(\mathrm{n}-\mathrm{k})}
$$

Keterangan: $\mathrm{k}=$ Jumlah variabel, $\mathrm{R}^{2}=$ koefisien determinan,

$$
\mathrm{n}=\text { Jumlah sampel }
$$

4. Kriteria pengujian: $\mathrm{H}_{0}$ diterima jika $\mathrm{F}_{\text {hitung }} \leq \mathrm{F}$ tabel, $\mathrm{H}_{1}$ diterima jika $\mathrm{F}$ hitung $>\mathrm{F}_{\text {tabel }}$

5. Kesimpulan : Dengan membandingkan langkah 3 dan 4 untuk menerima atau menolak hipotesis.

\section{B. Uji t}

1. $\mathrm{H}_{0}: \beta \mathrm{i}=0$, artinya variabel bebas tidak berpengaruh signifikan secara parsial terhadap variabel terikat.

$\mathrm{H}_{1}: \beta \mathrm{i} \neq 0$, artinya variabel bebas berpengaruh signifikan secara parsial terhadap variabel terikat.

2. Level of significan $(1-\alpha)=95 \%$, jumlah $n=258$ nasabah.

3. Uji statistik t :

$$
\mathrm{t}=\frac{\beta \mathrm{s}-\beta}{\mathrm{S} . \mathrm{E}[\beta \mathrm{s}]}
$$

Keterangan: $\mathrm{t}=\mathrm{t}_{\text {hitung, }}, \beta_{\mathrm{S}}=$ koefisien regresi, $\operatorname{Se}[\beta \mathrm{i}]=$ Standar error koefisien regresi

4. Kriteria pengujian:

$\mathrm{H}_{0}$ diterima jika $-\mathrm{t}_{\alpha / 2}: \mathrm{dk} \leq \mathrm{t}_{\text {hitung }} \leq \mathrm{t}_{\alpha / 2}: \mathrm{dk}$

$\mathrm{H}_{1}$ diterima jika $\mathrm{t}_{\text {hitung }}>\mathrm{t}_{\alpha / 2}: \mathrm{dk}$ atau $\mathrm{t}_{\text {hitung }}<-\mathrm{t}_{\alpha / 2}: \mathrm{dk}$

5.. Kesimpulan : Dengan membandingkan langkah 3 dan 4 untuk menerima atau menolak hipotesis. 


\section{HASIL PENELITIAN}

\section{Karakteristik Responden Berdasarkan Umur}

Dari 96 responden yang diamati, karakteristik responden berdasarkan umur tingkat pendidikan dan jenis pekerjaan ditunjukkan pada tabel berikut :

Tabel 2. Karakteristik Responden Berdasarkan Umur

\begin{tabular}{|c|c|c|}
\hline Umur ( Tahun ) & Jumlah ( fi ) & Prosentase ( \% ) \\
\hline $21-30$ & 17 & 17,7 \\
\hline $31-40$ & 29 & 30,2 \\
\hline $41-50$ & 39 & 40.6 \\
\hline $51-60$ & 11 & 11,5 \\
\hline Jumlah & 96 & 100 \\
\hline Tingkat Pendidikan & Jumlah ( fi ) & Prosentase ( \%) \\
\hline SMU & 35 & 36,4 \\
\hline Ahli Madya(D-3) & 30 & 31,3 \\
\hline Sarjana ( S-1 ) & 26 & 27,1 \\
\hline Magister (S-2) & 5 & 5,2 \\
\hline Jumlah & 96 & 100 \\
\hline & & Prosentase ( \%) \\
\hline Jenis Pekerjaan & Jumlah ( fi ) & 37,5 \\
\hline Pegawai Swasta & 36 & 52,1 \\
\hline Wiraswasta & 50 & 10,4 \\
\hline PNS & 10 & 100 \\
\hline Jumlah & 96 & \\
\hline Sug & & \\
\hline Diolah dari & & \\
\hline
\end{tabular}

Sumber : Diolah dari hasil koesioner

Tabel di atas menunjukkan, nasabah Kopdit CU Mandiri lebih dominan yang berumur 41 - 50 tahun kemudian $31-40$ tahun. Tingkat pendidikan dominan SMU dan Ahli Madya (D3). Sedngakan jenis pekerjaannya didominasi wiraswasta dan Pegawai Swasta.

\section{Pengaruh Variabel Harga Terhadap Persepsi Kualitas}

Hasil pengolahan data menunjukkan pengaruh variabel harga terhadap variabel persepsi kualitas sebagai berikut : 
Tabel 3. Coefficients ${ }^{\mathrm{a}}$ Variabel Harga

\begin{tabular}{|c|c|c|c|c|c|}
\hline \multirow{2}{*}{ Model } & \multicolumn{2}{|c|}{$\begin{array}{c}\text { Unstandardized } \\
\text { Coefficients }\end{array}$} & $\begin{array}{c}\text { Standardized } \\
\text { Coefficients }\end{array}$ & & \\
\cline { 2 - 4 } & $\mathrm{B}$ & Std. Error & Beta & $\mathrm{t}$ & Sig. \\
\hline (Constant) & 6.728 & 1.225 & & 5.490 & .000 \\
$\mathrm{H}$ & 1.070 & .105 & .723 & 10.156 & .000 \\
\hline
\end{tabular}

a. Dependent Variable: PK

Tabel 4. Koefisien Korelasi dan Determinasi Variabel Harga

\begin{tabular}{|c|c|c|c|c|}
\hline Model & $\mathrm{R}$ & R Square & $\begin{array}{c}\text { Adjusted R } \\
\text { Square }\end{array}$ & $\begin{array}{c}\text { Std. Error of the } \\
\text { Estimate }\end{array}$ \\
\hline 1 & $.723^{\mathrm{a}}$ & .523 & .518 & 1.665 \\
\hline
\end{tabular}

a. Predictors: (Constant), $\mathrm{H}$

Tabel 5. Nilai F. Hitung Variabel Harga

\begin{tabular}{|cc|c|c|c|c|c|}
\hline \multicolumn{2}{|c|}{ Model } & $\begin{array}{c}\text { Sum of } \\
\text { Squares }\end{array}$ & df & $\begin{array}{c}\text { Mean } \\
\text { Square }\end{array}$ & F & Sig. \\
\hline 1 & Regression & 286.050 & 1 & 286.050 & 103.144 & $.000^{\mathrm{a}}$ \\
& Residual & 260.690 & 94 & 2.773 & & \\
\multicolumn{2}{|r|}{ Total } & 546.740 & 95 & & & \\
\hline \multicolumn{2}{|r|}{ a. Predictors: (Constant), H }
\end{tabular}

b. Dependent Variable: PK

Tabel di atas, menunjukkan persamaan regresi : $\mathrm{PK}=6,728+$ $1,070 \mathrm{H}$. Persamaan tersebut menunjukkan bahwa variabel harga mempunyai pengaruh yang positif terhadap persepsi kualitas. Koefisien korelasi variabel harga dengan persepsi kualitas sangat kuat dengan nilai $r$ $=0,723$. Koefisien determinasinya sebesar $r^{2}=0,523$, artinya variabel Harga mampu menjelaskan 52,3 \% terhadap persepsi kualitas, sedangkan $47,7 \%$ dipengaruhi oleh faktor-faktor lain. Nilai thitung $>\mathrm{t}$ tabel dan $\mathrm{F}$ hitung $>\mathrm{F}$ tabel, maka variabel harga mempunyai pengaruh yang signifikan terhadap persepsi kualitas. 


\section{Pengaruh Variabel Reputasi Perusahaan Terhadap Persepsi Kualitas}

Hasil pengolahan data menunjukkan pengaruh variabel reputasi perusahaan terhadap variabel persepsi kualitas sebagai berikut :

Tabel 6. Coefficients ${ }^{\mathrm{a}}$ Variabel Reputasi

\begin{tabular}{|cc|c|c|c|c|c}
\hline & & \multicolumn{2}{|c|}{$\begin{array}{c}\text { Unstandardized } \\
\text { Coefficients }\end{array}$} & $\begin{array}{c}\text { Standardized } \\
\text { Coefficients }\end{array}$ & & \\
\cline { 2 - 5 } & Model & $\mathrm{B}$ & Std. Error & Beta & $\mathrm{t}$ & Sig. \\
\hline 1 & (Constant) & 6.562 & 1.290 & & 5.086 & .000 \\
& RP & 1.090 & .112 & .710 & 9.770 & .000 \\
\hline
\end{tabular}

a. Dependent Variable: PK

Tabel 7. Koefisien Korelasi dan Determinasi Variabel Reputasi

\begin{tabular}{|c|c|c|c|c|}
\hline Model & $\mathrm{R}$ & R Square & $\begin{array}{c}\text { Adjusted R } \\
\text { Square }\end{array}$ & $\begin{array}{c}\text { Std. Error of the } \\
\text { Estimate }\end{array}$ \\
\hline 1 & $.710^{\mathrm{a}}$ & .504 & .499 & 1.699 \\
\hline
\end{tabular}

a. Predictors: (Constant), RP

Tabel 8. Nilai F Hitung Variabel Reputasi

\begin{tabular}{|cc|c|c|c|c|c|}
\hline \multicolumn{1}{|c|}{ Model } & $\begin{array}{c}\text { Sum of } \\
\text { Squares }\end{array}$ & df & Mean Square & F & Sig. \\
\hline 1 & Regression & 275.463 & 1 & 275.463 & 95.451 & $.000^{\mathrm{a}}$ \\
& Residual & 271.277 & 94 & 2.886 & & \\
& Total & 546.740 & 95 & & & \\
\hline
\end{tabular}

a. Predictors: (Constant), RP

b. Dependent Variable: PK

Tabel di atas, menunjukkan persamaan regresi : $\mathrm{PK}=6,562+1,090$ RP. Persamaan tersebut menunjukkan bahwa variabel reputasi perusahaan mempunyai pengaruh yang positif terhadap persepsi kualitas. Koefisien korelasi variabel reputasi perusahaan dengan persepsi kualitas sangat kuat dengan nilai $r=0,710$. Koefisien determinasinya sebesar $r^{2}=0,504$, artinya variabel reputasi perusahaan mampu menjelaskan 50,4 \% terhadap persepsi kualitas, sedangkan 49,6 \% dipengaruhi oleh faktor-faktor lain. Nilai $\mathrm{t}$ hitung $>\mathrm{t}$ tabel dan $\mathrm{F}$ hitung $>\mathrm{F}$ tabel, hal ini berarti, variabel 
reputasi perusahaan mempunyai pengaruh yang signifikan terhadap persepsi kualitas .

\section{Pengaruh Variabel Persepsi Kualitas Terhadap Variabel \\ Loyalitas Nasabah}

Hasil pengolahan data menunjukkan pengaruh variabel persepsi kualitas terhadap variabel loyalitas nasabah sebagai berikut :

Tabel 9. Coefficients ${ }^{\mathrm{a}}$ Variabel Persepsi Kualitas

\begin{tabular}{|l|c|c|c|c|c|}
\hline \multirow{2}{*}{ Model } & \multicolumn{2}{|c|}{$\begin{array}{c}\text { Unstandardized } \\
\text { Coefficients }\end{array}$} & $\begin{array}{c}\text { Standardized } \\
\text { Coefficients }\end{array}$ & & \\
\cline { 2 - 4 } & $\mathrm{B}$ & Std. Error & Beta & $\mathrm{t}$ & Sig. \\
\hline $1 \quad$ (Constant) & 3.040 & 1.050 & & 2.895 & .005 \\
PK & .441 & .054 & .643 & 8.136 & .000 \\
\hline
\end{tabular}

a. Dependent Variable: LP

Tabel 10. Koefisien Korelasi dan Determinasi Variabel Persepsi Kualitas

\begin{tabular}{|c|c|c|c|c|}
\hline Model & $\mathrm{R}$ & R Square & $\begin{array}{c}\text { Adjusted R } \\
\text { Square }\end{array}$ & $\begin{array}{c}\text { Std. Error of the } \\
\text { Estimate }\end{array}$ \\
\hline 1 & $.643^{\mathrm{a}}$ & .413 & .407 & 1.249 \\
\hline
\end{tabular}

a. Predictors: (Constant),

PK

Tabel 11. Nilai F. Hitung Variabel Persepsi Kualitas

\begin{tabular}{|c|c|c|c|c|c|c|}
\hline \multicolumn{2}{|c|}{ Model } & $\begin{array}{c}\text { Sum of } \\
\text { Squares }\end{array}$ & df & Mean Square & F & Sig. \\
\hline 1 & Regression & 103.289 & 1 & 103.289 & 66.198 & $.000^{\mathrm{a}}$ \\
& Residual & 146.669 & 94 & 1.560 & & \\
Total & 249.958 & 95 & & & \\
\hline
\end{tabular}

a. Predictors: (Constant), PK

b. Dependent Variable: LP

Tabel di atas, menunjukkan persamaan regresi : $\mathrm{LP}=3,040+0,441$

PK. Persamaan tersebut menunjukkan, variabel persepsi kualitas mempunyai pengaruh yang positif terhadap loyalitas nasabah. Koefisien 
korelasi variabel persepsi kualitas dengan loyalitas nasabah sangat kuat dengan nilai $r=0,643$. Koefisien determinasinya sebesar $r^{2}=0,413$, artinya variabel persepsi kualitas mampu menjelaskan $41,3 \%$ terhadap loyalitas nasabah, sedangkan 58,7 \% dipengaruhi oleh faktor-faktor lain. Nilai $\mathrm{t}$ hitung $>\mathrm{t}$ tabel dan $\mathrm{F}$ hitung $>\mathrm{F}$ tabel, hal ini berarti, variabel persepsi kualitas mempunyai pengaruh yang signifikan terhadap loyalitas nasabah.

\section{Pengaruh Variabel Kepuasan Nasabah Terhadap Variabel}

\section{Loyalitas Nasabah}

Hasil pengolahan data menunjukkan pengaruh variabel kepuasan nasabah terhadap variabel loyalitas nasabah sebagai berikut:

Tabel 12. Coefficients ${ }^{\mathrm{a}}$ Variabel Kepuasan nasabah

\begin{tabular}{|cc|c|c|c|c|c|}
\hline & & \multicolumn{2}{|c|}{$\begin{array}{c}\text { Unstandardized } \\
\text { Coefficients }\end{array}$} & $\begin{array}{c}\text { Standardized } \\
\text { Coefficients }\end{array}$ & & \\
\cline { 2 - 5 } & Model & $\mathrm{B}$ & Std. Error & Beta & $\mathrm{t}$ & Sig. \\
\hline 1 & (Constant) & 9.032 & 1.369 & & 6.596 & .000 \\
& KP & .873 & .118 & .608 & 7.421 & .000 \\
\hline
\end{tabular}

a. Dependent Variable:

LP

Tabel 13. Koefisien Korelasi dan Determinasi Variabel Kepuasan Nasabah

\begin{tabular}{|c|c|c|c|}
\hline $\mathrm{R}$ & R Square & Adjusted R Square & Std. Error of the Estimate \\
\hline $.608^{\mathrm{a}}$ & .369 & .363 & 1.861 \\
\hline
\end{tabular}

a. Predictors: (Constant), KP

Tabel 14. Nilai F. Hitung Variabel Kepuasan Nasabah

\begin{tabular}{|c|c|c|c|c|c|}
\hline Model & $\begin{array}{l}\text { Sum of } \\
\text { Squares }\end{array}$ & df & Mean Square & $\mathrm{F}$ & Sig. \\
\hline $1 \quad$ Regression & 190.673 & 1 & 190.673 & 55.067 & $.000^{\mathrm{a}}$ \\
\hline Residual & 325.483 & 94 & 3.463 & & \\
\hline Total & 516.156 & 95 & & & \\
\hline
\end{tabular}

a. Predictors: (Constant), KP 


\begin{tabular}{|c|c|c|c|c|c|}
\hline Model & $\begin{array}{l}\text { Sum of } \\
\text { Squares }\end{array}$ & df & Mean Square & $\mathrm{F}$ & Sig. \\
\hline 1 Regression & 190.673 & 1 & 190.673 & 55.067 & $.000^{\mathrm{a}}$ \\
\hline Residual & 325.483 & 94 & 3.463 & & \\
\hline Total & 516.156 & 95 & & & \\
\hline
\end{tabular}

b. Dependent Variable: LP

Tabel di atas, menunjukkan persamaan regresi : $\mathrm{LP}=9,032+$ 0,873KP. Persamaan tersebut menunjukkan, variabel kepuasan nasabah mempunyai pengaruh yang positif terhadap Loyalitas nasabah. Koefisien korelasi variabel kepuasan nasabah dengan Loyalitas nasabah yang kuat dengan nilai $r=0,608$. Koefisien determinasinya sebesar $r^{2}=0,369$, artinya variabel kepuasan nasabah mampu menjelaskan 36,9\% terhadap Loyalitas nasabah, sedangkan 63,1\% dipengaruhi oleh faktor-faktor lain. Nilai $\mathrm{t}$ hitung $>\mathrm{t}$ tabel dan $\mathrm{F}$ hitung $>\mathrm{F}$ tabel, hal ini berarti, variabel kepuasan nasabah mempunyai pengaruh yang signifikan terhadap Loyalitas nasabah .

\section{Pengaruh Variabel Harga dan Reputasi Perusahaan Terhadap Variabel Persepsi Kualitas}

Hasil pengolahan data menunjukkan pengaruh variabel Harga dan Reputasi Perusahaan Terhadap Variabel Persepsi Kualitas sebagai berikut :

Tabel 15. Coefficients ${ }^{\mathrm{a}}$ Variabel Harga dan Reputasi

Perusahaan

\begin{tabular}{|cc|c|c|c|c|c|}
\hline \multirow{2}{*}{} & \multicolumn{2}{|c|}{$\begin{array}{c}\text { Unstandardized } \\
\text { Coefficients }\end{array}$} & $\begin{array}{c}\text { Standardized } \\
\text { Coefficients }\end{array}$ & & \multirow{2}{*}{ Sig. } \\
\cline { 2 - 5 } & Model & $\mathrm{B}$ & Std. Error & Beta & $\mathrm{t}$ & Sig. \\
\cline { 1 - 5 } 1 & (Constant) & 8.417 & 1.390 & & 6.054 & .000 \\
& $\mathrm{H}$ & .915 & .538 & .628 & 1.703 & .092 \\
& $\mathrm{RP}$ & .022 & .558 & .015 & .040 & .968 \\
\hline
\end{tabular}

a. Dependent Variable: PK 
Tabel 16. Koefisien Korelasi dan Determinasi Variabel Harga dan Reputasi

Perusahaan

\begin{tabular}{|c|c|c|c|c|}
\hline Model & $\mathrm{R}$ & R Square & $\begin{array}{c}\text { Adjusted R } \\
\text { Square }\end{array}$ & $\begin{array}{c}\text { Std. Error of the } \\
\text { Estimate }\end{array}$ \\
\hline 1 & $.643^{\mathrm{a}}$ & .413 & .401 & 1.829 \\
\hline
\end{tabular}

a. Predictors: (Constant), RP, H

Tabel 17. Nilai F. Hitung Variabel Harga dan Reputasi

Perusahaan

\begin{tabular}{|c|c|c|c|c|c|}
\hline Model & $\begin{array}{l}\text { Sum of } \\
\text { Squares }\end{array}$ & $\mathrm{df}$ & Mean Square & $\mathrm{F}$ & Sig. \\
\hline Regression & 219.183 & 2 & 109.591 & 32.748 & $.000^{\mathrm{a}}$ \\
\hline Residual & 311.223 & 93 & 3.346 & & \\
\hline Total & 530.406 & 95 & & & \\
\hline
\end{tabular}

a. Predictors: (Constant), RP, H

b. Dependent Variable: PK

Tabel di atas, menunjukkan persamaan regresi : $\mathrm{PK}=8,417+$ $0,915 \mathrm{H}+0,022 \mathrm{RP}$. Persamaan tersebut menunjukkan bahwa variabel harga dan reputasi perusahaan mempunyai pengaruh yang positif terhadap persepsi kualitas. Koefisien korelasi variabel harga dan reputasi perusahaan terhadap persepsi kualitas yang sangat kuat dengan nilai $\mathrm{r}=$ 0,643 . Koefisien determinasinya sebesar $r^{2}=0,413$, artinya variabel harga dan reputasi perusahaan mampu menjelaskan $41,3 \%$ terhadap persepsi kualitas, sedangkan 58,7 \% dipengaruhi oleh faktor-faktor lain. Nilai t hitung $>\mathrm{t}$ tabel dan $\mathrm{F}$ hitung $>\mathrm{F}$ tabel, hal ini berarti, variabel harga dan reputasi perusahaan mempunyai pengaruh yang signifikan secara parsial dan simultan terhadap persepsi kualitas.

\section{Pengaruh Variabel Persepsi Kualitas dan Kepuasan Nasabah Terhadap Variabel Loyalitas Nasabah}

Hasil pengolahan data menunjukkan pengaruh variabel persepsi kualitas dan kepuasan nasabah terhadap variabel Loyalitas Nasabah sebagai berikut : 
Tabel 18. Coefficients ${ }^{\mathrm{a}}$ Variabel Persepsi Kualitas dan Kepuasan

Nasabah

\begin{tabular}{|c|c|c|c|c|c|}
\hline \multirow[b]{2}{*}{ Model } & \multicolumn{2}{|c|}{$\begin{array}{l}\text { Unstandardized } \\
\text { Coefficients }\end{array}$} & \multirow{2}{*}{$\begin{array}{c}\text { Standardized } \\
\text { Coefficients }\end{array}$} & \multirow[b]{2}{*}{$\mathrm{t}$} & \multirow[b]{2}{*}{ Sig. } \\
\hline & B & Std. Error & & & \\
\hline $1 \quad$ (Constant) & 1.322 & .735 & & 1.799 & .075 \\
\hline PK & .914 & .047 & .927 & 19.263 & .000 \\
\hline KP & .017 & .069 & .012 & .247 & .805 \\
\hline
\end{tabular}

a. Dependent Variable: LP

Tabel 19. Koefisien Korelasi dan Determinasi Variabel Persepsi

Kualitas dan Kepuasan Nasabah

\begin{tabular}{|c|c|c|c|c|}
\hline Model & $\mathrm{R}$ & $\mathrm{R}$ Square & Adjusted R Square & $\begin{array}{c}\text { Std. Error of the } \\
\text { Estimate }\end{array}$ \\
\hline 1 & $.935^{\mathrm{a}}$ & .874 & .871 & .837 \\
\hline
\end{tabular}

a. Predictors: (Constant), KP, PK

Tabel 20. F. Nilai Hitung Variabel Persepsi Kualitas dan Kepuasan Nasabah

\begin{tabular}{|c|c|c|c|c|c|}
\hline Model & $\begin{array}{c}\text { Sum of } \\
\text { Squares }\end{array}$ & df & Mean Square & $\mathrm{F}$ & Sig. \\
\hline Regression & 450.927 & 2 & 225.463 & 321.451 & $.000^{\mathrm{a}}$ \\
\hline Residual & 65.230 & 93 & .701 & & \\
\hline Total & 516.156 & 95 & & & \\
\hline
\end{tabular}

a. Predictors: (Constant), KP, PK

b. Dependent Variable: LP

Tabel di atas, menunjukkan persamaan regresi : $\mathrm{LP}=1,322+$ 0,914PK $+0,017 \mathrm{KP}$. Persamaan tersebut menunjukkan, variabel persepsi kualitas dan kepuasan nasabah mempunyai pengaruh yang positif terhadap Loyalitas nasabah. Koefisien korelasi variabel kepuasan nasabah dan persepsi kualitas terhadap Loyalitas Nasabah sangat kuat dengan nilai $r=0,935$. Koefisien determinasinya sebesar $r^{2}=0,874$, artinya variabel kepuasan nasabah dan persepsi kualitas mampu menjelaskan 87,4 \% 
terhadap Loyalitas Nasabah, sedangkan 12,6 \% dipengaruhi oleh faktorfaktor lain. Nilai t hitung $>\mathrm{t}$ tabel dan $\mathrm{F}$ hitung $>\mathrm{F}$ tabel, hal ini berarti, variabel kepuasan nasabah dan persepsi kualitas mempunyai pengaruh yang signifikan secara parsial dan simultan terhadap loyalitas nasabah.

\section{PEMBAHASAN}

Berdasarkan hasil-hasil penelitian menunjukkan, variabel harga berpengaruh signifikan terhadap persepsi kualitas. Hal ini sejalan dengan hasil penelitian sebelumnya yang mengemukakan bahwa harga yang tinggi dari suatu merek seringkali dipersepsikan memiliki kualitas yang tinggi dan tidak peka terhadap persaingan potongan harga seperti merek-merek dengan harga yang rendah (Yoo, Donthu, dan Lee, 2000). Pada penelitian, Rao dan Monroe (1989) menyatakan harga berkorelasi positif terhadap persepsi kualitas. Sedangkan Chapman dan Wahlers (1999) menyatakan semakin meningkat harga maka persespsi konsumen terhadap kualitas juga semakin meningkat. Maka harga yang tinggi berperan sebagai sinyal terhadap kualitas suatu produk. Maka hipotesis yang diajukan dapat diterima.

Variabel reputasi perusahaan berpengaruh signifikan terhadap persepsi kualitas. Hal ini sejalan dengan hasil penelitian sebelumnya Zeithaml (1988) mengemukakan, kualitas yang dirasakan (perceived quality) dari suatu produk atau jasa erat hubungannya dengan reputasi yang diasosiasikan dengan nama merek. Reputasi perusahaan sangat penting dari sudut pandang nasabah untuk memberikan gambaran terhadap kualitas produk atau jasa yang dihasilkan (Brown dan Dacin, 1997). Herbig, Milewicz dan Golden (1994) menyatakan bahwa reputasi perusahaan dapat dilihat dari kompetensi perusahaan dan keunggulan dibandingkan dengan kompetitornya. Maka hipotesis yang diajukan dapat diterima.

Variabel persepsi kualitas berpengaruh signifikan terhadap variabel loyalitas nasabah. Hal ini sejalan dengan hasil penelitian sebelumnya persepsi kualitas jasa dengan lima dimensi kualitas jasa berhubungan positif terhadap minat beli ulang nasabah (Li dan Lee, 2001). Parasuraman, Zeithaml, dan Berry $(1985,1988)$ mengemukakan bahwa terdapat hubungan secara langsung antara persepsi kualitas dengan minat beli ulang. Persepsi kualitas yang dirasakan oleh konsumen akan berpengaruh terhadap kesediaan konsumen tersebut untuk membeli sebuah produk. Ini berarti bahwa semakin tinggi nilai yang dirasakan oleh konsumen, maka akan semakin tinggi pula kesediaan konsumen tersebut untuk akhirnya membeli (Chapman dan Wahlers, 1999). Menurut Dodds (1991) minat 
membeli dipengaruhi oleh nilai dari produk yang dievaluasi. Nilai merupakan perbandingan antara kualitas terhadap pengorbanan dalam memperoleh suatu produk atau layanan. Dengan adanya persepsi kualitas yang tinggi maka nasabah akan memiliki minat untuk menggunakan kembali jasa dari provider yang sama (Li dan Lee, 2001). Maka hipotesis yang diajukan dapat diterima.

Variabel kepuasan nasabah berpengaruh signifikan terhadap variabel loyalitas nasabah. Hal ini sejalan dengan hasil penelitian sebelumnya bahwa kepuasan nasabah/nasabah penting bagi para pemasar karena merupakan determinan dari pembelian ulang (Bearden dan Teel, 1983 dalam Woodside, Frey, dan Daly, 1989). Terdapat hubungan positif secara langsung antara kepuasan nasabah dengan minat beli ulang yang didukung oleh hasil-hasil penelitian terhadap berbagai kategori produk dan jasa (Anderson dan Sullivan, 1993; Bolton, 1998; Cronin dan Taylor, 1992; Fornell, 1992; Oliver, 1980; Patterson dan Spreng, 1997; Rust dan Zahorik, 1993; Selnes, 1998; Swan dan Trawick, 1981; Taylor dan Baker, 1994; Woodside et al, 1989 dalam Hellier, Geursen, Carr, dan Rickard, 2003). Dengan adanya kepuasan dari nasabah, maka nasabah akan memiliki minat untuk menggunakan kembali jasa dari provider yang sama (Hellier, Geursen, Carr, dan Rickard, 2002; Cronin dan Taylor, 1992). Hasil-hasil penelitian tersebut mengemukakan bahwa kepuasan nasabah secara keseluruhan pada layanan jasa berasosiasi kuat terhadap perilaku konsumen untuk menggunakan kembali jasa dari penyedia yang sama. Maka hipotesis yang diajukan dapat diterima.

Variabel Harga dan reputasi perusahaan mempunyai pengaruh yang positif terhadap persepsi kualitas . Demikian juga hasil penelitian bahwa variabel Persepsi Kualitas dan Kepuasan nasabah mempunyai pengaruh yang positif terhadap Loyalitas nasabah yang dibuktikan nilai koefisien regresi dan nilai $\mathrm{t}$ hitung $>\mathrm{t}$ tabel dan $\mathrm{F}$ hitung $>\mathrm{F}$ tabel. Maka hipotesis yang diajukan dapat diterima.

\section{KESIMPULAN DAN SARAN}

\section{Kesimpulan}

Berdasarkan hasil penelitian dan pembahasan terdapat beberapa kesimpulan :

1. Nasabah Kopdit CU Mandiri lebih dominan yang berumur 41 - 50 tahun kemudian 31 - 40 tahun. Jika dilihat dari tingkat pendidikan lebih dominan tingkat pendidikan SMU dan Ahli Madya (D3). 
Sedangkan jenis pekerjaan, nasabah Kopdit CU Mandiri lebih dominan wiraswasta dan Pegawai Swasta.

2. Variabel harga mempunyai pengaruh yang positif dan signifikan terhadap persepsi kualitas. Hal ini didukung hasil penelitian Yoo, Donthu, dan Lee, 2000 yang mengemukakan bahwa harga yang tinggi dari suatu merek seringkali dipersepsikan memiliki kualitas yang tinggi dan tidak peka terhadap persaingan potongan harga seperti merek-merek dengan harga yang rendah. Demikian juga dukungan penelitian Rao dan Monroe (1989) menyatakan bahwa harga berkorelasi positif terhadap persepsi kualitas. Penelitian Chapman dan Wahlers (1999) juga menyatakan bahwa semakin meningkat harga maka persespsi konsumen terhadap kualitas juga semakin meningkat. Oleh karena itu, harga yang tinggi berperan sebagai sinyal terhadap kualitas suatu produk. Maka hipotesis yang diajukan dapat diterima.

3. Variabel reputasi perusahaan mempunyai pengaruh yang positif dan signifikan terhadap persepsi kualitas. Hal ini sejalan dengan hasil penelitian Zeithaml (1988), mengemukakan bahwa kualitas yang dirasakan (perceived quality) erat hubungannya dengan reputasi yang diasosiasikan dengan nama merek. Herbig, Milewicz dan Golden (1994) menyatakan, reputasi perusahaan dapat dilihat dari kompetensi perusahaan dan keunggulan dibandingkan dengan kompetitornya. Maka hipotesis yang diajukan dapat diterima.

4. Variabel persepsi kualitas mempunyai pengaruh positif dan signifikan terhadap variabel loyalitas nasabah. Hal ini sejalan dengan hasil penelitian sebelumnya. Persepsi kualitas jasa dengan lima dimensi kualitas jasa berhubungan positif terhadap loyalitas nasabah ( $\mathrm{Li}$ dan Lee, 2001). Parasuraman, Zeithaml, dan Berry (1985, 1988) berpendapat terdapat hubungan secara langsung antara persepsi kualitas dengan loyalitas nasabah. Dengan adanya persepsi kualitas yang tinggi maka nasabah akan memiliki loyalitas nasabah untuk menggunakan kembali jasa dari provider yang sama (Li dan Lee, 2001). Maka hipotesis yang diajukan dapat diterima.

5. Variabel kepuasan nasabah mempunyai pengaruh yang positif dan signifikan terhadap variabel loyalitas nasabah. Hal ini sejalan dengan hasil penelitian bahwa kepuasan nasabah merupakan determinan dari loyalitas nasabah (Bearden dan Teel, 1983 dalam Woodside, Frey, dan Daly, 1989). Terdapat hubungan positif secara langsung antara kepuasan nasabah dengan loyalitas nasabah yang didukung oleh hasil-hasil penelitian terhadap berbagai kategori produk dan jasa (Anderson dan 
Sullivan, 1993; Bolton, 1998; Cronin dan Taylor, 1992; Fornell, 1992; Oliver, 1980; Patterson dan Spreng, 1997; Rust dan Zahorik, 1993; Selnes, 1998; Swan dan Trawick, 1981; Taylor dan Baker, 1994; Woodside et al, 1989 dalam Hellier, Geursen, Carr, dan Rickard, 2003). Dengan adanya kepuasan dari nasabah, maka nasabah akan memiliki loyalitas untuk menggunakan kembali jasa dari provider yang sama (Hellier, Geursen, Carr, dan Rickard, 2002; Cronin dan Taylor, 1992).

\section{Saran}

Berdasarkan hasil penelitian dan pembahasan ada beberapa saran yaitu :

1. Sebaiknya pihak Kopdit CU Mandiri lebih memperhatikan variabel harga yang terkait dengan konsumen sasaran maupun pesaing yang dihadapi. Demikian juga dengan variabel reputasi perusahaan agar tetap dapat dipertahankan yang terkait dengan pengalaman perusahaan, kompetensi perusahaan dan keunggulan perusahaan.

2. Sebaiknya pihak Kopdit CU Mandiri lebih memperhatikan variabel persepsi kualitas yang terkait dengan keandalan (Reliability), ketanggapan (Responsiveness), keyakinan (Assurance), empati (Empathy) dan Tangibles. Demikian juga dengan variabel kepuasan nasabah supaya tetap dipertahankan yang terkait dengan kesesuaian harapan , persepsi kinerja dan penilaian nasabah serta mempertahankan variabel loyalitas nasabah yang terkait dengan Repeat Purchase, Retention dan Referalls.

\section{DAFTAR PUSTAKA}

Aaker, David A. (1997), Should You Take Your Brand to Where the action is, Harvard Business Review, Vol. 75, Sept/Oct, p.135-143.

Anderson, Eugene W., Claes Fornell, dan Donald R. Lehmann (1994), "Customer Satisfaction, Market Share, and Profitabiliy : Finding from Sweden", Journal of Marketing, Vol. 58, p.53-66.

Chapman, Joe dan Russ Wahlers (1999), "A Revision and Empirical Test of the Extended Price-Perceived Quality Model", Journal of Marketing, p.53- 64.

Cobb-Walgren, Cathy, Cynthia A. Ruble, dan Naveen Donthu (1995), "Brand Equity, Brand Preference and Purchase Intent", Journal of Advertising, 24 (3), p.25-40.

Diana Puspitasari 2006, Analisis Pengaruh Persepsi Kualitas dan Kepuasan Nasabah Terhadap Minat Beli Ulang (Studi Kasus pada 
Maskapai Penerbangan Garuda Keberangkatan Semarang), Program Pasca Sarjana Universitas Diponegoro Semarang

Fornell, Claes (1992), "A National Customer Satisfaction Barometer : The Swedish Experience”, Journal of Marketing, Vol. 56, Jan, p.6-21.

Hawkins, Del I., Roger J. Best, dan Kenneth A. Coney (1998), Consumer Behavior :Building Marketing Strategy, Irwin/McGraw-Hill.

Hellier, Phillip K., Gus M. Geursen, Rodney A. Carr, dan John A. Rickard (2003), "Customer Repurchase Intention : A General Structural Equation Model", European Journal of Marketing, Vol. 37/11, p.1762-1800.

Kotler, Philip dan Armstrong, Gary, 2001. Prinsip-prinsip Pemasaran, Jilid 1, Alih Bahasa: Damos Sihombing, Edisi Kedelapan, Jakarta : Erlangga.

Li, Chieh-Lu dan Joohyun Lee (2001), "Dimensions of Service and Their Influence on Intention to Repurchase", Department of Leisure Studies Penn State University.

Parasuraman, A., Valerie A. Zeithaml, dan Leonard L. Berry (1988), “A Multiple Item Scale for Measuring Consumer Perception on Future Research", Journal of Marketing, Vol. 49/1.

Söderlund, Magnus dan Mats Vilgon (1999), "Customer Satisfaction and Links to Customer Profitability : an Empirical Examination of the Association Between Attitudes and Behavior", Working Paper Series in Business Administration, No. 1.

Sugiyono, 2004. Metode Penelitian Bisnis, Cetakan Keenam, Bandung: Alfabeta.

Ward, Steven, William Chitty, dan Brendan Achard (2005), "Brand Equity in an Online World", Journal of Internet Business, Vol. 2 (April).

Zeithaml, V. A. (1988), "Consumer Perceptions of Price, Quality, and Value : A Means-End Model and Synthesis of Evidence", Journal of Marketing, Vol. 52, July, p.52-54.

Zeithaml, V. A. dan Mario Jo Bitner (1996), Service Marketing, McGrawHill Companies Inc., New York.

Staff.uny.ac.id/sites/default/files/pendidikan/Dra. Endang Mulyatiningsih, M.Pd./Metode Penentuan Sampel.pdf 